University of New Hampshire

University of New Hampshire Scholars' Repository

$4-15-2014$

\title{
Rates of sustainable forest harvest depend on rotation length and weathering of soil minerals
}

\author{
Matthew A. Vadeboncoeur \\ University of New Hampshire - Main Campus, matt.vad@unh.edu \\ Steven P. Hamburg \\ Environmental Defense Fund \\ Ruth D. Yanai \\ SUNY College of Environmental Science and Forestry \\ Joel D. Blum \\ University of Michigan
}

Follow this and additional works at: https://scholars.unh.edu/ersc

Part of the Earth Sciences Commons

\section{Recommended Citation}

Vadeboncoeur, M.A., Hamburg, S.P., Yanai, R.D., Blum, J.D. Rates of sustainable forest harvest depend on rotation length and weathering of soil minerals. (2014) Forest Ecology and Management, 318, pp.

194-205. doi:10.1016/j.foreco.2014.01.012

This Article is brought to you for free and open access by the Institute for the Study of Earth, Oceans, and Space (EOS) at University of New Hampshire Scholars' Repository. It has been accepted for inclusion in Earth Systems Research Center by an authorized administrator of University of New Hampshire Scholars' Repository. For more information, please contact Scholarly.Communication@unh.edu. 


\title{
Rates of sustainable forest harvest depend on rotation length and weathering of soil minerals
}

\author{
Matthew A. Vadeboncoeur \\ University of New Hampshire \\ Steven P. Hamburg \\ Environmental Defense Fund
}

Ruth D. Yanai

SUNY College of Environmental Science and Forestry

Joel D. Blum

University of Michigan

(C) 2015, Elsevier. Licensed under the Creative Commons BY-NC-ND 4.0 International user license.

This postprint (accepted manuscript version) is made available by the authors in accordance with Elsevier's author agreement.

The version of record is available at $\mathrm{http}$ ://dx.doi.org/10.1016/i.foreco.2014.01.012

This document should be cited as:

Vadeboncoeur M.A., Hamburg S.P., Yanai R.D., Blum J.D. 2014. Rates of sustainable forest harvest depend on rotation length and weathering of soil minerals. Forest Ecology and Management, 318: 194-205. 


\section{$1 \underline{\text { Abstract }}$}

2 Removals of forest biomass in the northeastern US may intensify over the coming 3 decades due to increased demand for renewable energy. For forests to regenerate successfully

4 following intensified harvests, the nutrients removed from the ecosystem in the harvested

5 biomass (including $\mathrm{N}, \mathrm{P}, \mathrm{Ca}, \mathrm{Mg}$, and $\mathrm{K}$ ) must be replenished through a combination of plant-

6 available nutrients in the soil rooting zone, atmospheric inputs, weathering of primary minerals,

7 biological $\mathrm{N}$ fixation, and fertilizer additions. Few previous studies (especially in North

8 America) have measured soil nutrient pools beyond exchangeable cations, but over the long

9 rotations common in this region, other pools which turn over more slowly are important. We

10 constructed nutrient budgets at the rotation time scale for three harvest intensities and compared

11 these with detailed soil data of exchangeable, organic, and primary mineral stocks of in soils

12 sampled in 15 northern hardwood stands developed on granitic till soils in the White Mountain

13 region of New Hampshire, USA. This comparison can be used to estimate how many times each

14 stand might be harvested without diminishing productivity or requiring fertilization. Under

15 1990s rates of $\mathrm{N}$ deposition, $\mathrm{N}$ inputs exceeded removals except in the most intensive

16 management scenario considered. Net losses of $\mathrm{Ca}, \mathrm{K}, \mathrm{Mg}$, and $\mathrm{P}$ per rotation were potentially

17 quite severe, depending on the assumptions used.

18 Biologically accelerated soil weathering may explain the lack of observed deficiencies in

19 regenerating forests of the region. Sites differed widely in the long-term nutrient capital

20 available to support additional removals before encountering limitations (e.g., a fourfold

21 difference in available $\mathrm{Ca}$, and a tenfold difference in weatherable $\mathrm{Ca}$ ). Intensive short-rotation

22 biomass removal could rapidly deplete soil nutrient capital, but traditional long rotations, even

23 under intensive harvesting, are unlikely to induce nutrient depletion in the $21^{\text {st }}$ century.

24 Weatherable P may ultimately limit biomass production on granitic bedrock (in as few as 6

25 rotations). Understanding whether and how soil weathering rates respond to nutrient demand

26 will be critical to determining long-term sustainability of repeated intensive harvesting over

27 centuries.

\section{Key words}

29 ecosystem budget; whole-tree harvesting; sustainable forestry; soil weathering; apatite;

30 bioenergy; calcium; phosphorus 
$\underline{\text { Introduction }}$

Deciduous forests in the northeastern United States have a long history of exploitation as a source of fuel and timber. New harvesting methods emerged in the 1970s, in which branches and low-value trees were chipped and sold as fuel rather than left on site. Studies of the increased nutrient removal associated with such harvests raised concern about the potential depletion of important nutrients, especially Ca, from forest soils (White 1974, Mann et al. 1988, Federer et al. 1989, Hornbeck et al. 1990, Adams et al. 2000). Interest in forest bioenergy has increased again recently (e.g. Malmsheimer et al. 2008, Richter et al. 2009), driven by energy price volatility and the goals of reducing net greenhouse gas emissions and dependence on imported energy.

Sustainable forestry comprises management practices that maintain the capacity of the

42 forest to provide important ecosystem services in the future, including water quality,

43 biodiversity, species composition, and forest productivity (Janowiak and Webster 2010, Walker

44 et al. 2010, Berger et al. 2013). Here we address potential productivity declines due to nutrient

45 removal in stands harvested repeatedly. From this perspective, sustainability requires that

46 removals of nutrients from ecosystems be balanced by inputs to plant-available pools (Sverdrup and Svensson 2002, Flueck 2009). Though many forests in the northeastern USA remain productive after having been harvested and regrown twice or more, continued harvest removals and associated hydrologic losses of nutrients will eventually reduce net primary productivity unless ecosystem inputs increase above current estimates. Observations of nutrient availability and productivity in whole-tree harvested stands have yielded mixed results, at least for the relatively short time scales examined thus far (Thiffault et al. 2011). Though analogous forest systems elsewhere in the world are often fertilized to replace nutrients where biomass removals are high (e.g. northern Europe, Stupak et al. 2008), forest fertilization is not currently common in the northeastern USA.

Exchangeable nutrients have historically been considered the nutrient pool most available to plants and of greatest relevance in assessing productivity (Marschner 1995). However, exchangeable pools contain only a small fraction of the nutrients required by a regrowing forest

59 (e.g. Likens et al. 1994; 1998). Indeed, at decadal time scales, even forests undergoing vigorous

60 biomass accumulation appear not to deplete exchangeable soil nutrient pools (Johnson et al.

61 1991, 1997, Bélanger et al. 2004). More relevant to longer-term productivity is the rate of 
supply of these nutrients from less available pools or sources external to the ecosystem, relative to the rate needed to support regrowth (Rastetter and Shaver 1992, Craine 2009).

Nutrients enter forest ecosystems via atmospheric deposition and the weathering of geologic substrates. Nitrogen is not present in many parent materials but is also fixed microbially from the atmosphere. In regions of granitic parent material, base cations $(\mathrm{Ca}, \mathrm{Mg}$, $\mathrm{K}$ ) are weathered primarily from silicate minerals, while the most important source of $\mathrm{P}$ is the accessory mineral apatite $\left(\mathrm{Ca}_{5}\left(\mathrm{PO}_{4}\right)_{3}(\mathrm{~F}, \mathrm{Cl}, \mathrm{OH})\right)$. Apatite can also be an important source of $\mathrm{Ca}$ in granitic soils (Blum et al. 2002; Nezat et al. 2004), because it weathers more rapidly than silicate minerals (Allen and Hajek 1989). Long-term weathering rates have been estimated from soil profiles in the White Mountain region (Nezat et al. 2004; Schaller et al. 2010). Weathering rate estimates are inherently variable and difficult to compare across methods and locations (Klaminder et al. 2011, Futter et al. 2012). However, weathering rates that are required to close ecosystem budgets (Likens et al. 1996, 1998, Hyman et al. 1998) are sometimes an order of magnitude greater than measured long-term rates estimated from the degree of depletion of soil profiles relative to their parent material. This discrepancy is a common finding when comparing estimates of weathering by different methods in similar soils (Table 1), despite the expectation that current rates should be lower than long-term means due to the decline in weathering rate as soils age (Taylor and Blum 1995). This discrepancy has been attributed to elevated acid deposition (Langan et al. 1995), but hydrologic Ca losses cannot be fully explained by observed acidic inputs (Hamburg et al. 2003). Rooting-zone soil weathering rates are difficult to assess at the watershed scale, where net fluxes are small relative to the large dynamic stocks, uncertainties are often large (Likens and Bormann 1995, Yanai et al. 2012), soils vary over short spatial scales, and significant chemical contributions to streamflow may occur below the rooting zone.

Another potential explanation for high apparent weathering rates is that soil weathering may be accelerated when there is increased biotic demand (Hamburg et al. 2003). The removal of large amounts of biomass over the past $\sim 150$ years is a significant new disturbance in forests of the region. Wind, ice damage, and infrequent fires have been the dominant forms of disturbance over the past 10,000 years, and generally leave most nutrient capital on site. Regrowing forests may shift resource allocation towards the acquisition of nutrients other than $\mathrm{N}$, such as $\mathrm{P}$ (Rastetter et al. 2013). Ectomycorrhizal fungi are known to weather primary minerals (such as apatite) by etching mineral surfaces with organic acid exudates under 
93 conditions where the weathering products (such as P) are limiting (Landeweert et al. 2001;

94 Hoffland et al. 2004; Van Scholl et al. 2008). Greatly elevated rates of apparent mineral

95 weathering have been observed in aggrading pine mesocosms (Bormann et al. 1998, Balogh-

96 Brunstad et al. 2008), and may occur in rapidly aggrading forest stands as well (Hamburg et al.

97 2003, Bélanger et al. 2004).

\section{Research Approach and Objectives}

Analyses of the sustainability of forestry practices typically compare managementinduced nutrient losses to nutrient inputs via atmospheric deposition and weathering (e.g. Sverdrup and Svensson, 2002; Duchesne and Houle, 2008). Building on work by Federer et al. (1989), we extend this approach by comparing net nutrient loss per rotation to nutrient stocks, under a range of assumptions about harvest intensity and nutrient availability. Specifically, we ask:

1. What is the net nutrient balance per rotation under various harvesting scenarios?

2. How much variation exists in nutrient stocks (exchangeable, organically bound, and apatite) among stands that are ostensibly similar in species composition and soil type?

3. Assuming that exchangeable and organically bound nutrients can be depleted over multiple rotations, which nutrient eventually becomes limiting (i.e. is exhausted first) under each harvesting scenario?

4. If apatite in the rooting zone is considered available, how many additional rotations would be possible?

The first question relates directly to "strong" definitions of sustainability, whereby resource stocks must be maintained at current levels over time (e.g. Goodland and Daly, 1996; Flueck, 2009). The second question seeks to characterize variation in soil nutrient stocks at spatial scales relevant to management decisions, in order to avoid depleting ecosystems beyond critical thresholds. The third and fourth questions stem from the observation that ecosystems may continue to function normally despite some level of stock depletion.

Our approach necessarily involves many assumptions about 1) the magnitude of fluxes that are difficult to estimate across a variable landscape and 2) how fluxes will change over time with increasing nutrient stress. When simplifying assumptions must be made, we have chosen 
122 those that likely lead to an overestimation bias of the number of rotations that can be sustainably

123 harvested in the northern hardwood region.

\section{$124 \underline{\text { Methods }}$}

\section{Study Sites}

We sampled soils in 15 deciduous forest stands of varying age in the White Mountain region of central New Hampshire (Figure 1; Table 2). Dominant species included American beech (Fagus grandifolia Ehrh.), sugar maple (Acer saccharum Marsh.), and yellow birch (Betula alleghaniensis Britton) in mature stands, and white birch (Betula papyrifera Marsh.), red maple (Acer rubrum L.), and pin cherry (Prunus pensylvanica L. f.) in younger stands. One site (B1) was a former pasture dominated by red spruce (Picea rubens Sarg.) mixed with northern hardwoods, and the area sampled at the Hubbard Brook Experimental Forest (HBEF) has red spruce and balsam fir (Abies balsamea L.) at higher elevations. Soils were primarily well or moderately drained, coarse-loamy, mixed-frigid typic Haplorthods developed on glacial till parent material derived from granitoid and high-grade metamorphic silicate rocks.

\section{Sample Collection}

Three $0.5 \mathrm{~m}^{2}$ quantitative soil pits were excavated at each of 14 study sites (excluding HBEF) in 2003-4, following methods described in detail by Vadeboncoeur et al. (2012). The Oie and Oa horizons were collected in their entirety. Mineral soil samples were quantitatively excavated in several depth increments to the top of the $\mathrm{C}$ horizon, sieved to $12 \mathrm{~mm}$ in the field, weighed, homogenized, and subsampled. The top $25 \mathrm{~cm}$ of the $\mathrm{C}$ horizon was also quantitatively excavated in at least one pit per stand.

Soil data for HBEF were assembled from multiple data sets collected in three first-order watersheds on the same south-facing slope. Forest floor samples (60 pin-block samples) were collected at Watershed 6 in 2002 (Yanai et al. 2013). Mineral soils were sampled in 59 quantitative soil pits in the adjacent Watershed 5 in 1983; one from each of four elevation zones was randomly chosen for analysis (Hamburg et al. 2003). C horizon samples from Watershed 1, approximately $1 \mathrm{~km}$ to the east, were analyzed by Nezat et al. (2004), but sampling was not quantitative; $\mathrm{C}$ horizon mass in the top $25 \mathrm{~cm}$ was estimated as the mean of that measured in the other 14 stands. 


\section{Laboratory Analysis}

Organic horizon samples were air-dried, subsampled, and dried to constant mass at $60^{\circ} \mathrm{C}$.

153 Oa samples were sieved to $6 \mathrm{~mm}$ and Oie samples were milled. Mineral soil samples were air154 dried and sieved to $2 \mathrm{~mm}$; subsamples were oven-dried at $105^{\circ} \mathrm{C}$. Total $\mathrm{N}$ concentrations were measured on a CE Instruments Model NC2100 elemental analyzer. Oa and mineral soil samples were subjected to a sequential extraction procedure adapted from Nezat et al. (2007) to measure exchangeable, organic, and weatherable apatite fractions for each mineral nutrient. Each extraction step was conducted for 24 hours at $20^{\circ} \mathrm{C}$. First, exchangeable cations were extracted with $1 \mathrm{M} \mathrm{NH}_{4} \mathrm{Cl}$. Then, soil organic matter was extracted in $30 \% \mathrm{H}_{2} \mathrm{O}_{2}$. Finally, each sample was extracted with $1 \mathrm{M} \mathrm{HNO}_{3}$, which has been shown to congruently dissolve apatite in contact with the solution, though $\sim 30 \%$ of total apatite may be shielded by more resistant silicate minerals (Nezat et al. 2007). Oa samples were then subjected to a final extraction in concentrated $\mathrm{HNO}_{3}$ for 3 hours in a microwave digester. Oie samples were microwave-digested in concentrated $\mathrm{HNO}_{3}$ rather than sequentially extracted, because they had little mineral matter.

165 Concentrations of $\mathrm{Ca}, \mathrm{Mg}, \mathrm{K}$, and $\mathrm{P}$ in all soil extracts were measured on an Optima $3300 \mathrm{DV}$

166 ICP-Optical Emission Spectrometer. Mineral soil samples from HBEF were not subjected to the $167 \quad \mathrm{H}_{2} \mathrm{O}_{2}$ extraction; $\mathrm{P}$ is the only element for which $\mathrm{H}_{2} \mathrm{O}_{2}$ extracts a substantial amount relative to 168 the first (exchangeable) extraction in mineral soils. We estimated $\mathrm{H}_{2} \mathrm{O}_{2}$-extractable $\mathrm{P}$ at $\mathrm{HBEF}$ 169 using the mean ratio of total mineral soil $\mathrm{C}: \mathrm{P}_{\mathrm{H} 2 \mathrm{O} 2}$ across the other 14 stands.

\section{Scenario Description}

We predicted ecosystem nutrient depletion over multiple rotations based on a range of assumptions about nutrient inputs and outputs (called scenarios I and II), harvest intensity (called

173 scenarios $\mathrm{a}, \mathrm{b}$, and c), and the stocks of nutrients considered available to the ecosystem over

174 multiple rotations (called scenarios 1, 2, and 3). We used combinations of scenarios to address our specific research questions, and report summarized results across the 15 stands.

The net depletion or enrichment of each nutrient was calculated as the difference between

177 the nutrient removal per rotation and the ecosystem inputs (atmospheric deposition and soil

178 weathering) during the rotation length. We conducted this calculation under two sets of

179 assumptions about ecosystem inputs and outputs: I) using pedogenic time-scale average 
weathering inputs and assuming zero baseline streamflow output, or II) using weathering rates estimated from ecosystem budgets and hydrologic outputs (Table 3).

\section{Ecosystem input and output data}

Bulk atmospheric deposition and streamflow fluxes of all macronutrients have been monitored at HBEF since the 1960's (Likens 2012a, 2012b, 2012c); we used mean inputs and outputs for the period 1985-2004. We did not include dry deposition of $\mathrm{N}$ as an input, due to high landscape-scale variability (Lovett et al. 1997) and its small magnitude (e.g. 3-6\% of total N inputs; Weathers et al., 2006). We included total dissolved $\mathrm{P}$ analyzed in bulk collector solutions, which may somewhat overstate ecosystem inputs due to the mineralization of locally derived particulate P (e.g. pollen), despite quality-control standards that exclude visibly contaminated samples (Stelzer et al. 2002).

We calculated harvest-induced leaching, which we included in all scenarios, as the cumulative 22-year difference between streamwater nutrient flux from HBEF Watershed 5 (clearcut by whole-tree harvest in 1983) and that of the adjacent reference watershed after accounting for the small pre-treatment difference between these streams (Yanai et al. 2005; Likens 2012b,c). Increases in export over the reference baseline were similar in magnitude to those measured by Hornbeck et al. (1990) throughout New England for 3 years after clearcutting.

Scenario I: We used stand-specific weathering inputs of $\mathrm{Ca}, \mathrm{K}, \mathrm{Mg}$, and $\mathrm{P}$ calculated by Nezat et al. (2004) and Schaller et al. (2010), based on profile depletion relative to titanium. One stand (M5) lacked a $\mathrm{C}$ horizon, making it unsuitable for this approach, so we used mean weathering rates from the other 13 stands. Two others ( $\mathrm{C} 1$ and $\mathrm{H} 6)$ had irregular element ratio profiles for one or more nutrients; for these elements we also used mean weathering estimates. We conservatively assumed zero baseline (non-harvest-related) leaching of nutrients under this scenario.

Scenario II: We included 20-year observed streamflow losses of nutrients (Likens et al. 2012c), and also included recent budget-based weathering estimates from HBEF Watershed 6 for $\mathrm{Ca}$ (Likens et al. 1998) and nearby Cone Pond for K and Mg (Hyman et al., 1998). Phosphorus weathering is highly uncertain (Yanai 1992, Vadeboncoeur 2013); we estimated P weathering from the Likens et al. (1998) estimate of Ca weathering, assuming that $17 \%$ of long-term $\mathrm{Ca}$ weathering was in the form of apatite (as estimated by Nezat et al. 2004). This estimate of 
210 current $\mathrm{P}$ weathering is in the middle of estimates based on other calculation approaches

211 (Vadeboncoeur 2013).

212 Biomass removal scenario data

213 To estimate net nutrient balances per rotation, we paired nutrient budgets under scenarios

214 I and II with estimates of total nutrient export per harvest (in scenarios a, b, and c, below).

215 Scenario a: Stem-only removal on a $\sim 100$-year rotation is a common forest management

216 practice in which merchantable saw and pulp logs are removed from a site, while branches, poor

217 quality trees, and smaller trees are left on site, either standing or as slash. To estimate the

218 nutrient capital removed in this type of harvest, we used the 2007 vegetation inventory from 550-

219745 m elevation at HBEF Watershed 6. Wood and bark contents (Siccama 2007) were summed

220 for all trees $>12.7 \mathrm{~cm} \mathrm{DBH}$ to estimate nutrient removals for a heavy timber and pulpwood

221 harvest. Basal area for this stand was $25 \mathrm{~m}^{2} \mathrm{ha}^{-1}$, and estimated biomass removal was 125 dry

222 metric tons per hectare. Biomass and nutrient content may be somewhat lower than is typical for

223 the region (Fahey et al. 2005), but the allometry and nutrient stocks are uniquely well validated

224 (Arthur et al. 2001).

225 Scenario b: A more intensive scenario is whole-tree harvesting on the same 100-year

226 rotation. This is the same as the previous scenario, except that non-merchantable parts of trees

227 are also removed for bioenergy use, rather than being left on site. We assumed winter harvesting

228 of deciduous trees, with no removal of foliage. We used the same vegetation inventory as in the

229 previous scenario to calculate the biomass stock of all trees $>2 \mathrm{~cm} \mathrm{DBH}$, subtracting leaves and

230 the small amount of slash estimated by Arthur et al. (2001). Biomass removal in this scenario is

231187 dry metric tons per hectare, a 50\% increase over the stem-only scenario.

232 Scenario : : The most intensive scenario we modeled was whole-tree harvesting on a

233 shorter, $\sim 35$ year rotation, which would theoretically maximize the biomass harvest rate, at least

234 over the first few harvests. To represent the biomass removed from a forest of this age, we used

235 an inventory taken in 2011 in four stands in the Bartlett Experimental Forest that were clearcut

236 between 1975 and 1980. Nutrient concentrations (Fatemi 2007) and allometric equations

237 (Fatemi et al. 2011) were specific to two of these stands. Basal area averaged $32 \mathrm{~m}^{2} \mathrm{ha}^{-1}$.

238 Allowing for $40 \%$ of branch biomass to be left on site due to typical harvest inefficiency (Briedis

239 et al., 2011; somewhat more than in the experimental W5 harvest), this harvest would yield 156

240 dry metric tons per hectare, about $240 \%$ as much biomass as scenario b on an annualized basis. 
While we modeled removals as clearcuts for the sake of simplicity and to reduce the

242 number of scenarios, removals associated with partial cuts on shorter rotations (e.g. 30\% of basal 243 area every 30 years) are likely at least as great as scenario a (if stem only) or b (if whole trees are 244 removed).

\section{Soil nutrient availability}

246 For each study stand, we calculated "available" stocks of $\mathrm{N}, \mathrm{Ca}, \mathrm{K}, \mathrm{Mg}$, and $\mathrm{P}$ in each of

247 three scenarios. We report the means (of 3 or more soil pits) within each stand, and the variation 248 within and among stands is reported as coefficient of variation.

249 Scenario 1: We first assumed that only exchangeable and organically bound and 250 complexed nutrient pools would become available over one to several harvest rotations. For the 251 Oa organic nutrient content, we used the extraction with the best correlation between organic 252 matter content and the concentration of each nutrient (the $20^{\circ} \mathrm{C}^{-\mathrm{HNO}_{3}}$ extraction for $\mathrm{K}$ and $\mathrm{Mg}$, 253 and a microwave $\mathrm{HNO}_{3}$ extractable for $\mathrm{Ca}$ and $\mathrm{P}$ ), to avoid including the often significant silicate 254 mineral content of the Oa horizon.

255 Scenario 2: Because $\mathrm{P}$ is the least abundant geologically derived nutrient in the soil 256 parent material relative to biotic demand, and because apatite may be an important source of $\mathrm{Ca}$ 257 to forest ecosystems in the region (Blum et al. 2002; Hamburg et al. 2003, Yanai et al. 2005) our 258 second scenario adds $1 \mathrm{~N} \mathrm{HNO}_{3}$-extractable apatite in the B horizon to the "available" stock of 259 Ca and P.

260 Scenario 3: In the most optimistic scenario, we assumed that apatite in the top $25 \mathrm{~cm}$ of 261 the $\mathrm{C}$ horizon was also biologically available. Federer et al. (1989) assumed that unweathered 262 parent material became available to biological uptake only at a rate equal to the physical 263 denudation rate. However, 5-7\% of total fine root biomass mass in the 14 studied stands was 264 found in the C horizon (Yanai et al. 2006, Park et al. 2007), which appears to be typical for the 265 region (Donahue 1940). It is not known to what extent these roots provide access to C-horizon 266 nutrients, but it is conceivable that carbon allocation to deep roots and mycorrhizae might 267 increase when weathering-derived nutrients are limiting (Chapin et al. 1985, George et al. 1997, 268 Bever et al. 2009, Smits et al. 2012). 


\section{Soil stock depletion calculations}

The number of supportable rotations $(N)$ was calculated as the ratio of the available nutrient stock $(S)$ to nutrient removal per rotation $(R)$, accounting for other ecosystem-scale input $272\left(F_{\text {in }}\right)$ and output $\left(F_{\text {out }}\right)$ fluxes over the rotation length $\left(T_{R}\right)$ :

273

$$
N=\frac{S}{R+T_{R}\left(F_{\text {out }}-F_{\text {in }}\right)}
$$

We used only the more conservative net nutrient budget scenario (I) for these estimates. Supportable rotations under varying harvest intensities were compared under scenarios Ia1, Ib1, and Ic1. We examined variability of depletable nutrient stocks among stands by calculating the range in the number of 100-year whole-tree harvest rotations required to deplete exchangeable plus organic nutrient stocks, and exchangeable plus organic plus apatite stocks (scenarios Ib2 and $\mathrm{Ib} 3)$.

\section{$\underline{\text { Results }}$}

Assembling stand-level budgets for various types of rotations shows that $\mathrm{N}$ inputs exceed outputs in all except the most intensive harvesting scenario (c) (Table 4). On the other hand, nutrient balances were negative (net ecosystem depletion) for $\mathrm{Ca}$ under all management and nutrient input-output scenarios. Magnesium and K showed net depletion under all scenarios except Ia and Ib, and P showed net depletion in all scenarios except IIa.

The nutrients examined differed in patterns of variation among stands when we examined stocks in the exchangeable fraction plus organic matter (Table 5). Nitrogen and K, which varied about twofold among stands (with CVs $\sim 20 \%$ ) showed considerably less variation than $\mathrm{Ca}, \mathrm{Mg}$, and $\mathrm{P}$, which varied at least fivefold $(\mathrm{CVs}>33 \%)$. Variation among stands in apatite stocks in the B horizon was substantially less than in the $\mathrm{C}$ horizon (Table 5).

The number of rotations that could be supported by the complete mineralization and uptake of all organic and exchangeable nutrients in the $\mathrm{O}$ and $\mathrm{B}$ horizons varied considerably among stands and especially among harvest scenarios (Figure 2). Calcium was most commonly predicted to be depleted first in the bole-only scenario, though $\mathrm{K}$ limitation was encountered first at the Bald Mountain stands. Bole-only harvesting could be supported for one to four additional rotations by these stocks. In the whole-tree harvest scenarios, $\mathrm{Ca}, \mathrm{K}$, or $\mathrm{Mg}$ limited production, depending on the stand, before two additional rotations were completed. In all cases, 
calculations based on input-output budget II (assuming observed hydrologic losses and weathering rates calculated by difference) indicated more rapid depletion of soil nutrients than the calculations based on budget I (assuming zero non-harvest-induced hydrologic output and long-term mean weathering rates from profile depletion).

Including B-horizon apatite as a P stock that could be made available via accelerated mycorrhizal weathering dramatically increased estimates of potential future production (Table

304 6). This limit ranges widely from six to $>40$ rotations under a 100-year whole-tree harvesting 305 rotation. However, unless the weathering of other Ca-bearing minerals also accelerates, $\mathrm{Ca}$ 306 supply may present a more immediate constraint; B-horizon apatite stocks of Ca supply only an 307 additional one to five rotations. If roots and mycorrhizal fungi were able to utilize the much 308 larger stocks of apatite in the $\mathrm{C}$ horizon (an uncertain proposition, given the low density of roots 309 at this depth), supportable 100-year whole-tree harvests would more than double in some cases, 310 though by very little where the $\mathrm{C}$ horizon is shallow or poor in apatite (Table 6).

\section{$311 \quad$ Discussion}

\section{Validity of Assumptions}

313 Our estimates likely represent an upper bound to the number of harvests that each stand 314 would be able to sustain without additional nutrient inputs. This is because when assumptions 315 were needed we intentionally biased the result in this direction. For example, our use of HBEF

316 Watershed 6 for harvestable nutrient content estimates may understate regional standing biomass

317 nutrient stocks in mature stands, because the biomass of this stand is on the low side of regional

318 variation (Leak and Smith 1996, Fahey et al. 2005, van Doorn et al. 2011, Reiners et al. 2012,

319 Rastetter et al. 2013). On the other hand, errors are potentially quite large when applying 320 allometric equations and nutrient contents beyond the areas for which they were developed 321 (Melson et al. 2011). Biomass at stands C8 and C9 at the Bartlett Experimental Forest is 35\% 322 and 26\% greater than at Watershed 6, respectively, and estimated removals under WTH range 323 from $20 \%$ greater for $\mathrm{P}$ to $90 \%$ higher for $\mathrm{Ca}$, indicating the potential for more rapid depletion of 324 nutrients if these sites were cut and regained their current biomass and nutrient content in 100 325 years. Measurements of base cations in biomass at a similar site in Québec (Tremblay et al. 326 2012) fall between the HBEF and Bartlett ranges, while biomass and nutrient removals estimated 
327 for a whole-tree harvested stand of unreported age in northern NH (Hornbeck et al. 1990) were 328 somewhat lower than the HBEF Watershed 5 estimates.

329 We also assumed constant atmospheric inputs into the future, which is more likely for 330 some nutrients than for others. Widespread declines in base cation deposition (Hedin et al. 1994) 331 generally preceded the 20-year period we used. Phosphorus deposition may also have decreased 332 in the region, as mineral aerosols are the dominant atmospheric source of both base cations and 333 of P (Newman 1995), and some local sources (notably road dust and fly ash) have likely 334 decreased over the past century. $\mathrm{N}$ deposition has very recently declined sharply in the region 335 (Bernal et al. 2012). Balancing removals under scenarios Ia and Ib would require deposition of 3362.7 and $4.5 \mathrm{~kg} \mathrm{ha}^{-1} \mathrm{y}^{-1}$ respectively, plus enough to balance any hydrologic $\mathrm{N}$ losses that continue 337 under reduced atmospheric loading. The depletion of $\mathrm{N}$ accumulated in SOM from elevated $\mathrm{N}$ 338 deposition in the $20^{\text {th }}$ century would reduce the impact of this potential future imbalance, as 339 would biological $\mathrm{N}$ fixation, which has been observed in aggrading ecosystems on N-poor 340 substrates (Bormann et al. 2002).

341 We assumed that the entire organic pool of nutrients was available over the relevant time 342 scale, though the mineralization of organically bound $\mathrm{N}$ and $\mathrm{P}$ may be limited by overall OM 343 decomposition rates. Much of this material is fairly recalcitrant, though mycorrhizal fungi under 344 nutrient-limited conditions can be expected to allocate $\mathrm{C}$ to enzymes that may liberate these 345 nutrients from complex organic substrates, even at a net energy cost (Orwin et al. 2011).

346 Furthermore, we assumed that forest production and nutrient uptake would continue until 347 available stocks of nutrients were fully depleted, though in reality uptake and growth would slow 348 should this limit be approached.

349 Our assumption of constant nutrient content for successive tree rotations may counteract 350 our overestimates of nutrient supply. Nutrient concentrations tend to decrease with nutrient stress 351 in foliage, and likely also in wood and bark (DeWalle et al. 1991), though this has not been 352 extensively studied. Species differ widely in overall wood nutrient concentrations and also in the 353 ability to remobilize nutrients from heartwood (Meerts 2002). To the extent that some current 354 nutrient uptake represents "luxury" uptake, i.e. uptake beyond an amount that affects production, 355 such decreases would increase the number of potential rotations, as future nutrient exports in the 356 biomass would be smaller than assumed in our analyses. However, for limiting nutrients, large 
decreases in uptake would necessarily be met by decreases in production (Craine 2009). Species composition would likely also change to favor species with greater nutrient-use efficiency.

Another possible underestimation is our use of the top $25 \mathrm{~cm}$ of $\mathrm{C}$ horizon nutrient stocks, despite $\mathrm{C}$ horizons which extended deeper than this at most sites (Vadeboncoeur et al. 2012). However, making efficient use of nutrients deeper than this would likely entail a large increase in root and mycorrhizal density and activity at these depths, which are not traditionally considered part of the rooting zone.

\section{Weathering}

In scenario I, our calculations conservatively assumed only the long-term, pedogenic time, mean weathering rate from observed profile depletion relative to titanium (Schaller et al. 2010). Current rates should theoretically be lower than long-term means, due to a reduction in weatherable mineral surfaces and depletion of the more rapidly weatherable minerals as soils age (Taylor and Blum 1995). However, current watershed budgets (Table 1) require a rate of soil weathering greater than the long-term mean, or the depletion of soil organic and exchangeable pools, to explain the large observed difference between outputs of base cations in streamwater and inputs in atmospheric deposition in both aggrading and steady-state stands (Likens and Bormann 1995, Romanowicz et al. 1996).

It is difficult to explain how forests are regenerating and accumulating biomass Ca while also losing $\mathrm{Ca}$ and other cations in streamflow at accelerated rates, unless weathering rates are elevated far above their long-term means (Hamburg et al. 2003; Yanai et al. 2005). Current

377 biotic demand for $\mathrm{P}$ and base cations might exceed the long-term steady state due to prior harvest 378 removals, early stages of ecosystem $\mathrm{N}$ saturation, a warming climate, and increased atmospheric $379 \mathrm{CO}_{2}$ concentrations (Peñuelas et al. 2012). Alternatively, weathering below the rooting zone 380 (which has not been monitored over time) may lead to nutrient losses and weathering rate 381 estimates that overstate inputs available for plant uptake. Distinguishing between these 382 possibilities has important implications for predicting nutrient balance in future rotations. 
1999; Rosling et al. 2004), which may be important in stands where these nutrients are predicted to be depleted before $\mathrm{Ca}$ (Table 2). Feldspar minerals contain the majority of total $\mathrm{Ca}$ and $\mathrm{K}$ in granite-derived soils (Nezat et al. 2007) but less work has been done to determine whether the slower process of feldspar weathering might be influenced by biotic demand for these elements.

If apatite can be made available to trees at an accelerated rate when demand is increased, then this raises many interesting and unanswered questions. If $\mathrm{Ca}$ deficiency drives apatite 393 weathering in excess of P demand, excess P may become occluded, associated with $\mathrm{Al}$ and Fe 394 secondary minerals. Alternatively, if apatite is weathered at an increased rate due to biotic 395 demand for P, Ca may leach out of the system in stream water; this process could be one 396 explanation for the sustained elevation of streamwater of Ca from Watershed 5 at HBEF for at 397 least 20 years following whole-tree harvesting (Yanai et al. 2005). Allocation of carbon to 398 deeper roots and associated mycorrhizal fungi (Bever et al. 2009, Kiers et al. 2011) may 399 represent a significant carbon cost to the trees, with implications for aboveground productivity. 400 Allocation to mycorrhizal fungi may account for $20 \%$ of primary production (Hobbie 2006), 401 and appears to vary with the availability of $\mathrm{N}$ and P (Treseder 2004, Vadeboncoeur 2010, Vicca 402 et al. 2012).

403 A better understanding of biogeochemical cycling in forests under various management 404 regimes on a range of soils will require more geographically specific data on baseline weathering 405 rates as well as in-situ estimates of short-term weathering rates in regenerating stands. Over the 406 short term (one to several rotations) such data could help to differentiate sustainable from 407 unsustainable forestry practices (see, for example, the differences between weathering scenarios 408 I and II in Table 4). However, if weathering rates can be upregulated in response to biological 409 demand, over the long term these rates may matter less than the nutrient capital in weatherable 410 primary minerals. Except in cases where rapid geologic uplift and erosion continuously supply 411 fresh parent material, an unfertilized forest can be regarded as effectively closed on a 412 management-relevant time scale for macronutrients other than $\mathrm{N}$, because removals are much 413 greater than atmospheric inputs. By treating weathering as an unknown internal flux and 414 examining the total weatherable pools of each nutrient we can put upper limits on the total long415 term removal that a soil can ultimately support (Table 6), independent of the rate at which 416 weathering might occur. 


\section{Implications for Management and Policy}

Shorter rotations would yield more biomass in the short term, but much less biomass in the long term (Table 7) due to the higher nutrient concentrations of biomass removed, as well as fewer years of atmospheric and weathering inputs between harvests. For this reason, at any harvest intensity, longer rotation lengths would be more sustainable than shorter ones.

While we use a single value for harvest-induced leaching of nutrients across all harvest scenarios, more moderate harvesting scenarios (patch cutting, strip cutting, single-tree selection, diameter-limit cutting) may reduce overall leaching losses, even if harvests are more frequent (Hornbeck and Leak 1992). However, harvest-induced leaching accounts for only about $20 \%$ of total rotation $\mathrm{Ca}$ losses under the whole-tree harvesting scenario; the bulk of nutrient capital exported each rotation is in the biomass.

It is also possible, depending in part on harvest conditions, that changes in site nutrient status will affect the species composition of the regenerating forest, with consequent effects on timber value and wildlife habitat. These effects might be expected to precede declines in overall forest productivity, as species more tolerant of low-nutrient conditions become more competitive. Species changes over multiple rotations will depend not only on nutrient availability, but also on climate change, dispersal mechanics, and silvicultural practice. These effects are typically considered aspects of sustainability (Worrell and Hampson 1997), and may affect the decisions of land owners and foresters regarding the intensity of future management.

\section{Landscape-scale variation}

Our data show a high degree of variability in soil nutrient stocks at the landscape scale.

All stands included in this analysis are upland sites generally representative of the type harvested in the region; half had been clearcut since 1970. Variability can be dramatic even at small spatial scales. For example, the mean coefficient of variation (CV) among the three $0.5 \mathrm{~m}^{2}$ pits at each stand in B-horizon apatite Ca was 67\%. Nezat et al. (2004) found similar variation in nutrient

443 due to the amount of soil, though total soil nutrient contents also vary with the depth of the $\mathrm{O}$

444 horizon and parent material. Thus, nutrient content increases with the depth of these horizons

445 and decreases with the presence of coarse clasts in soil. 
lowest stocks of nutrients tended to be located on Conway granite, while those on other types of granitic bedrock (particularly Concord granite at Bald Mountain) had dramatically greater Chorizon $\mathrm{Ca}$ and $\mathrm{P}$ capital (Table 2). These differences reflect documented differences in apatite abundance between these lithologies (Billings and Wilson 1965). Also of relevance in glaciated

452 landscapes is the parent material in the source region "upstream" of each stand, which may have contributed significantly to the local glacial till; in glaciated areas the till source area may be more important than underlying bedrock in predicting potential nutrient supply (Figure 1; Hornbeck et al. 1997).

\section{Regional-scale variation}

The stands in our study do not represent the full range of soil types in the region.

Sustainable removal rates of $\mathrm{Ca}$, for example, would be much higher in sites with carbonatebearing parent materials. Nezat et al. (2008) characterized $\mathrm{HNO}_{3}$-extractable Ca stocks (including both apatite and carbonates) across the northeastern United States from New York to Maine, including three of our study stands, which were generally low, especially relative to sites on carbonate-bearing sedimentary parent material. Both the HBEF and Cone Pond watersheds

463 have lower-than-average streamwater Ca export compared with other small watersheds in 464 northern and western New England (Hornbeck et al. 1997), suggesting generally higher Ca availability beyond the often thin granitic tills of the White Mountains.

Pairing chemical analyses of sequential extracts from soils with estimates of nutrient removal per rotation, as we have done here, allows for robust sustainability assessments across a 468 wide variety of temperate forest ecosystems. Unfortunately, systematic data on soil mass and mineral content do not exist at a regional scale. NRCS soil classifications focus on physical and limited chemical characteristics of the soils, which provide some important information (texture, 471 rockiness, organic concentrations) but are insufficient to address questions of long-term nutrient 472 supply. These classifications, along with site-index guidelines relating soil texture and slope 473 position to species composition and production (e.g. Leak 1978), are a reasonable starting place

474 for estimating long-term production at the stand and landscape scales, but ultimately such 475 assessments will require detailed information on soil mineralogy. Existing regional analyses 476 classifying ecosystem sensitivity to acid deposition (e.g. Robinson, 1997) give a rough sense of 477 parent material controls on base cation supply, but do not address soil primary P stocks. New 
continental-scale soil chemistry datasets (Smith et al., 2011) provide coarse but potentially useful data on regional variation in soil $\mathrm{P}$ and other nutrients.

\section{Fertilization}

Fertilization could be used to mitigate or reverse nutrient depletion from harvest removals. However, the possibility of short-term nutrient pulses in runoff has raised concern, especially because the most cost-effective time to fertilize is during harvesting (Stupak et al. 2008). Fertilizers and the labor required to apply them may be quite costly relative to the marginal time-discounted value of forest products removed, especially if the return interval is long. Globally, more intensive forestry regimes (predominantly plantations) often include earlyand mid-rotation fertilizations to match short-term uptake demand (Fox et al. 2007; Laclau et al 2009), though rarely have whole-rotation nutrient mass balances been considered in fertilization recommendations.

Over the long term, hardened (slow-release) wood ash might be an economical alternative to mined mineral fertilizers, especially as global exploitable phosphate reserves become depleted (Smil 2000). From an ecosystem perspective, the application of locally sourced wood ash to regenerating forests is an appealing solution, as it closes the nutrient cycle. However, care must be taken regarding heavy metal mobility, appropriate application rate, and timing (Karltun et al. 2008). While gains in productivity in the current rotation may not be substantial without also adding N (Pitman 2006), our analysis indicates that returning mineral nutrients may be critical to sustaining future rotations.

\section{Policy Implications}

Forest harvest guidelines generally recommend against whole-tree harvesting at sites with wet or thin soils, steep slopes, or rare species (Stupak et al. 2008, Evans et al. 2010). Coarse sandy soils or those with a history of fire or intensive agriculture have also been suggested as indicators of vulnerability to nutrient loss (Hallett and Hornbeck 2000). Our analysis shows that such guidelines might not identify some sites that are vulnerable in the long-term to nutrient depletion; some sites that the analysis indicates are quite vulnerable to nutrient depletion were clearcut by the US Forest Service in the past several decades.

Across much of the Northeast, depending on the parent material, nutrient stocks are probably adequate to support one to several whole-tree rotations at about a 100-year interval without substantial ecosystem consequences. However, short-rotation heavy cuts have a high 
509 risk of depleting nutrient capital due to greater total biomass removal rates and shorter recovery

510 time, and should not be considered without additional research into mineral soil weathering rates

511 and nutrient stocks at a range of spatial and temporal scales. Currently, woody biomass prices

512 are too low for such intensive management to be economically viable, but this situation could

513 change rapidly if policies favoring bioenergy were adopted at the state or federal level, so it is

514 important to ensure that best-practices guidelines recognize this risk. Biomass accumulation in

515 stands that our analysis indicates are vulnerable to nutrient depletion are similar to that in stands

516 throughout the region (Fatemi et al. 2011, Reiners et al. 2012), and if 100-year rotation lengths

517 are utilized there should be little concern that whole-tree harvesting might lead to a net depletion

518 in exchangeable base cations (Johnson et al. 1991, Bélanger et al. 2004) for the foreseeable

519 future. However, more research is needed to determine which forests might face nutrient

520 depletion with future harvesting and whether bioenergy can be derived from these forests into the $52122^{\text {nd }}$ century.

\section{Acknowledgements}

524 We thank the many dedicated student workers who carefully excavated soil pits and 525 processed samples. A. Klaue conducted lab analyses, and C.R. Levine calculated young-stand 526 nutrient content from data collected by F. Fatemi and others. HBEF forest floor nutrient 527 concentrations, other than for N, were analyzed by Tom Siccama. HBEF stream water and 528 precipitation chemistry datasets were collected by G.E. Likens, with financial support from the 529 Andrew W. Mellon Foundation and NSF, including the LTER and LTREB programs. We thank

530 Erik Hobbie, Scott Ollinger, Mark Ducey, John Aber, and Julie Bryce for comments that 531 improved the manuscript.

532 This work was supported by NSF grants DEB0235650 and DEB9810221 and a Switzer 533 Environmental Fellowship to MAV. We thank the Parker Family for continued stewardship of 534 the Bald Mountain research sites. The Bartlett and Hubbard Brook Experimental Forests are 535 operated by the USDA Forest Service Northern Research Station, and Hubbard Brook is a NSF536 funded Long Term Ecological Research network site. This work is a contribution to the Hubbard 537 Brook Ecosystem Study. 


\section{$\underline{\text { References }}$}

Adams, M. B., J. A. Burger, A. B. Jenkins, and L. Zelazny. 2000. Impact of harvesting and atmospheric pollution on nutrient depletion of eastern US hardwood forests. Forest Ecology and Management 138:301-319.

Allen, B. I., and B. F. Hajek. 1989. Mineral occurrence in soil environments. Pages 199-278 in B. Dixon and S. B. Weed, editors. Minerals in Soil Environments, 2nd edition. Soil Science Society of America, Madison, WI.

April, R., R. Newton, and L. T. Coles. 1986. Chemical weathering in two Adirondack watersheds: past and present-day rates. Geological Society of America Bulletin 97:1232-1238. doi: 10.1130/00167606(1986)97<1232:CWITAW>2.0.CO;2.

Arthur, M. A., S. P. Hamburg, and T. G. Siccama. 2001. Validating allometric estimates of aboveground living biomass and nutrient contents of a northern hardwood forest. Canadian Journal of Forest Research 31:11-17. doi: 10.1139-cjfr-31-1-11.

Bailey, S. W., J. W. Hornbeck, C. T. Driscoll, and H. E. Gaudette. 1996. Calcium inputs and transport in a base-poor forest ecosystem as interpreted by Sr isotopes. Water Resources Research 32:707-719. doi: 10.1029/95WR03642.

Bain, D. C., M. J. Roe, D. M. L. Duthie, and C. M. Thompson. 2001. The influence of mineralogy on weathering rates and processes in an acid-sensitive granitic catchment. Applied Geochemistry 16:931-937. doi: 10.1016/S0883-2927(00)00071-8.

Balogh-Brunstad, Z., C. K. Keller, B. T. Bormann, R. O’Brien, D. Wang, and G. Hawley. 2008. Chemical weathering and chemical denudation dynamics through ecosystem development and disturbance. Global Biogeochemical Cycles 22:1-11. doi: 10.1029/2007GB002957.

Bélanger, N., D. Paré, M. Bouchard, and G. Daoust. 2004. Is the use of trees with superior growth a threat to soil nutrient availability? A case study with Norway spruce. Canadian Journal of Forest Research 34:560-572. doi: 10.1139/x03-216.

Berger, A. L., B. Palik, A. W. D’Amato, S. Fraver, J. B. Bradford, K. Nislow, D. King, and R. T. Brooks. 2013. Ecological impacts of energy-eood harvests: lessons from whole-tree harvesting and natural disturbance. Journal of Forestry 111:139-153. doi: 10.5849/jof.12.020.

Bernal, S., L. O. Hedin, G. E. Likens, S. Gerber, and D. C. Buso. 2012. Complex response of the forest nitrogen cycle to climate change. Proceedings of the National Academy of Sciences of the United States of America 109:3406-11. doi: 10.1073/pnas.1121448109.

Bever, J. D., S. C. Richardson, B. M. Lawrence, J. Holmes, and M. Watson. 2009. Preferential allocation to beneficial symbiont with spatial structure maintains mycorrhizal mutualism. Ecology Letters 12:13-21. doi: 10.1111/j.1461-0248.2008.01254.x.

Billings, M. P., and J. R. Wilson. 1965. Chemical analyses of rocks and rock-minerals from New Hampshire. New Hampshire Department of Resources and Economic Develoment, Concord, NH.

Blum, J. D., A. Klaue, C. A. Nezat, C. T. Driscoll, C. E. Johnson, T. G. Siccama, C. Eagar, T. J. Fahey, and G. E. Likens. 2002. Mycorrhizal weathering of apatite as an important calcium source in basepoor forest ecosystems. Nature 417:729-731. doi: 10.1038/nature00793.

Bormann, B. T., C. K. Keller, D. Wang, and F. H. Bormann. 2002. Lessons from the sandbox: is unexplained nitrogen real? Ecosystems 5:727-733. doi: 10.1007/s10021-002-0189-2. 
Bormann, B. T., D. Wang, F. H. Bormann, G. Benoit, R. April, and M. C. Snyder. 1998. Rapid, plantinduced weathering in an aggrading experimental ecosystem. Biogeochemistry 43:129-155. doi: 10.1023/A:1006065620344.

Briedis, J. I., J. S. Wilson, J. G. Benjamin, and R. G. Wagner. 2011. Biomass retention following wholetree, energy wood harvests in central Maine: adherence to five state guidelines. Biomass and Bioenergy 35:3552-3560. Elsevier Ltd. doi: 10.1016/j.biombioe.2011.05.018.

Chapin, F. S., A. J. Bloom, and H. A. Mooney. 1985. Resource limitation in plants - an economic analogy. Annual Review of Ecology and Systematics 16:363-392. doi: 10.1146/annurev.es.16.110185.002051.

Clayton, J. L., and W. F. Megahan. 1986. Erosional and chemical denudation rates in the Southwestern Idaho batholith. Earth Surface Processes and Landforms 11:389-400. doi: 10.1002/esp.3290110405.

Craine, J. M. 2009. Resource Strategies of Wild Plants. Page 352. Princeton University Press, Princeton, NJ.

DeWalle, D. R., B. R. Swistock, R. G. Sayre, and W. E. Sharpe. 1991. Spatial variations of sapwood chemistry with soil acidity in Appalachian forests. Journal of Environmental Quality 20:486-491. American Society of Agronomy, Crop Science Society of America, and Soil Science Society of America. doi: 10.2134/jeq1991.00472425002000020024x.

Donahue, R. L. 1940. Forest-site quality studies in the Adirondacks 1. Tree growth as related to soil morphology. Cornell University, Ithaca, NY. Memoir 229.

Duchesne, L., and D. Houle. 2008. Impact of nutrient removal through harvesting on the sustainability of the boreal forest. Ecological Applications 18:1642-1651.

Egli, M., A. Mirabella, and G. Sartori. 2008. The role of climate and vegetation in weathering and clay mineral formation in late Quaternary soils of the Swiss and Italian Alps. Geomorphology 102:307324. Elsevier B.V. doi: 10.1016/j.geomorph.2008.04.001.

Evans, A. M., R. T. Perschel, and B. A. Kittler. 2010. Revised assessment of biomass harvesting and retention guidelines. Forest Guild, Santa Fe, NM.

Fahey, T. J., T. G. Siccama, C. T. Driscoll, G. E. Likens, J. L. Campbell, C. E. Johnson, J. J. Battles, J. D. Aber, J. J. Cole, M. C. Fisk, P. M. Groffman, S. P. Hamburg, R. T. Holmes, P. A. Schwarz, and R. D. Yanai. 2005. The biogeochemistry of carbon at Hubbard Brook. Biogeochemistry 75:109-176.

Fatemi, F. R. 2007. Aboveground biomass and nutrients in developing northern hardwood stands in New Hampshire, USA. M.Sc. Thesis, State University of New York College of Environmental Science and Forestry, Syracuse, NY.

Fatemi, F. R., R. D. Yanai, S. P. Hamburg, M. A. Vadeboncoeur, M. A. Arthur, R. D. Briggs, and C. R. Levine. 2011. Allometric equations for young northern hardwoods: the importance of age-specific equations for estimating aboveground biomass. Canadian Journal of Forest Research 41:881-891. doi: $10.1139 / \times 10-248$.

Federer, C. A., J. W. Hornbeck, L. M. Tritton, C. W. Martin, R. S. Pierce, and C. T. Smith. 1989. Longterm depletion of calcium and other nutrients in eastern US forests. Environmental Management 13:583-601. doi: 10.1007/BF01874965.

Flueck, W. T. 2009. Evolution of forest systems: the role of biogeochemical cycles in determining sustainable forestry practices. Ecology and Society 14:r4.

Fox, T. R., H. L. Allen, T. J. Albaugh, R. Rubilar, and C. A. Carlson. 2007. Tree nutrition and forest fertilization of pine plantations in the southern United States. Southern Journal of Applied Forestry 31:5-11. 
Futter, M. N., J. Klaminder, R. W. Lucas, H. Laudon, and S. J. Köhler. 2012. Uncertainty in silicate mineral weathering rate estimates: source partitioning and policy implications. Environmental Research Letters 7:024025. doi: 10.1088/1748-9326/7/2/024025.

George, E., B. Seith, C. Schaeffer, and H. Marschner. 1997. Responses of Picea, Pinus and Pseudotsuga roots to heterogeneous nutrient distribution in soil. Tree Physiology 17:39-45. doi: 10.1093/treephys/17.1.39.

Goodland, R., and H. Daly. 1996. Environmental sustainability: universal and non-negotiable. Ecological Applications 6:1002-1017. JSTOR.

Hallett, R. A., and J. W. Hornbeck. 2000. Managing oak and pine stands on outwash sands: protecting plant nutrients. Northern Journal of Applied Forestry 17:57-61.

Hamburg, S. P., R. D. Yanai, M. A. Arthur, J. D. Blum, and T. G. Siccama. 2003. Biotic control of calcium cycling in northern hardwood forests: acid rain and aging forests. Ecosystems 6:399-406. doi: 10.1007/s10021-002-0174-9.

Hedin, L. O., L. Granat, G. E. Likens, T. A. Buishand, J. N. Galloway, T. J. Butler, H. Rodhe, and T. Adri Buishand. 1994. Steep declines in atmospheric base cations in regions of Europe and North America. Nature 367:351-354. doi: 10.1038/367351a0.

Hobbie, E. A. 2006. Carbon allocation to ectomycorrhizal fungi correlates with belowground allocation in culture studies. Ecology 87:563-9. doi: 10.1890/05-0755.

Hoffland, E., T. W. Kuyper, H. Wallander, C. Plassard, A. A. Gorbushina, K. Haselwandter, S. Holmström, R. Landeweert, U. S. Lundström, A. Rosling, R. Sen, M. M. Smits, P. A. W. van Hees, and N. van Breemen. 2004. The role of fungi in weathering. Frontiers in Ecology and the Environment 2:258-264. doi: 10.1890/1540-9295(2004)002[0258:TROFIW]2.0.CO;2.

Hornbeck, J. W., S. W. Bailey, D. C. Buso, and J. B. Shanley. 1997. Streamwater chemistry and nutrient budgets for forested watersheds in New England: variability and management implications. Forest Ecology and Management 93:73-89. doi: 10.1016/S0378-1127(96)03937-0.

Hornbeck, J. W., and W. B. Leak. 1992. Ecology and management of northern hardwood forests in New England. USDA Forest Service Northeastern Research Station, General Technical Report NE-159.

Hornbeck, J. W., C. T. Smith, C. W. Martin, L. M. Tritton, and R. S. Pierce. 1990. Effects of intensive harvesting on nutrient capitals of three forest types in New England. Forest Ecology and Management 30:55-64.

Hyman, M. E., C. E. Johnson, S. W. Bailey, J. W. Hornbeck, and R. H. April. 1998. Chemical weathering and cation loss in a base-poor watershed. Geological Society of America Bulletin 110:85-95. doi: 10.1130/0016-7606(1998)110<0085:CWACLI >2.3.CO;2.

Janowiak, M. K., and C. R. Webster. 2010. Promoting ecological sustainability in woody biomass harvesting. Journal of Forestry 108:16-23.

Johnson, C. E., A. H. Johnson, and T. G. Siccama. 1991. Whole-tree clear-cutting effects on exchangeable cations and soil acidity. Soil Science Society of America Journal 55:502-508. doi: 10.2136/sssaj1991.03615995005500020035x.

Johnson, C. E., R. B. Romanowicz, and T. G. Siccama. 1997. Conservation of exchangeable cations after clear-cutting of a northern hardwood forest. Canadian Journal of Forest Research 27:859-868. doi: 10.1139/cjfr-27-6-859.

Johnson, D. W., L. K. Mann, D. C. West, J. W. Hornbeck, D. W. Cole, C. W. Martin, H. Riekerk, C. T. Smith, L. M. Swank, L. M. Tritton, and D. H. van Lear. 1988. Effects of whole-tree and stem-only 
clearcutting on postharvest hydrologic nutrient losses, nutrient capital, and regrowth. Forest Science 34:412-428.

Karltun, E., A. Saarsalmi, M. Ingerslev, M. Mandre, S. Andersson, T. Gaitnieks, R. Ozolinčius, and I. Varnagiryte-Kabasinskiene. 2008. Wood ash recycling - possibilities and risks. Pages 79-108 in D. Röser, A. Asikainen, K. Raulund-Rasmussen, and I. Stupak, editors. Sustainable Use of Forest Biomass for Energy - A Synthesis with Focus on the Baltic and Nordic Region. Springer. doi: 10.1007/978-1-4020-5054-1_4.

Kiers, E. T., M. Duhamel, Y. Beesetty, J. A. Mensah, O. Franken, E. Verbruggen, C. R. Fellbaum, G. A. Kowalchuk, M. M. Hart, A. Bago, T. M. Palmer, S. a West, P. Vandenkoornhuyse, J. Jansa, and H. Bücking. 2011. Reciprocal rewards stabilize cooperation in the mycorrhizal symbiosis. Science 333:880-882. doi: 10.1126/science.1208473.

Kirkwood, D. E., and H. W. Nesbitt. 1991. Formation and evolution of soils from an acidified watershed: Plastic Lake, Ontario, Canada. Geochimica et Cosmochimica Acta 55:1295-1308. doi: 10.1016/0016-7037(91)90308-R.

Klaminder, J., R. W. Lucas, M. N. Futter, K. H. Bishop, S. J. Köhler, G. Egnell, and H. Laudon. 2011. Silicate mineral weathering rate estimates: are they precise enough to be useful when predicting the recovery of nutrient pools after harvesting? Forest Ecology and Management 261:1-9. Elsevier B.V. doi: 10.1016/j.foreco.2010.09.040.

Laclau, J.-P., J. Ranger, J. L. de Moraes Gonçalves, V. Maquère, A. V. Krusche, A. T. M'Bou, Y. Nouvellon, L. Saint-André, J.-P. Bouillet, M. de Cassia Piccolo, and P. Deleporte. 2010. Biogeochemical cycles of nutrients in tropical Eucalyptus plantations. Forest Ecology and Management 259:1771-1785. doi: 10.1016/j.foreco.2009.06.010.

Landeweert, R., E. Hoffland, R. D. Finlay, T. W. Kuyper, and N. van Breemen. 2001. Linking plants to rocks: ectomycorrhizal fungi mobilize nutrients from minerals. Trends in Ecology \& Evolution 16:248-254. doi: 10.1016/S0169-5347(01)02122-X.

Langan, S. J., M. E. Hodson, D. C. Bain, R. A. Skeffington, and M. J. Wilson. 1995. A preliminary review of weathering rates in relation to their method of calculation for acid sensitive soil parent materials. Water, Air, and Soil Pollution 85:1075-1081. doi: 10.1007/BF00477124.

Leak, W. B. 1978. Relationship of species and site index to habitat in the White Mountains of New Hampshire. USDA Forest Service Northeastern Forest Experiment Station Research Paper NE-397.

Leak, W. B., and M.-L. Smith. 1996. Sixty years of management and natural disturbance in a New England forested landscape. Forest Ecology and Management 81:63-73. doi: 10.1016/03781127(95)03662-8.

Lelong, F., C. Dupraz, P. Durand, and J. F. Didon-Lescot. 1990. Effects of vegetation type on the biogeochemistry of small catchments (Mont Lozere, France). Journal of Hydrology 116:125-145. doi: 10.1016/0022-1694(90)90119-I.

Likens, G. E. 2012a. Chemistry of Bulk Precipitation at HBEF WS-6. Hubbard Brook Ecosystem Study. Hubbard Brook Ecosystem Study, http://www.hubbardbrook.org/data/dataset.php?id=20.

Likens, G. E. 2012b. Chemistry of Streamwater at HBEF WS-6. Hubbard Brook Ecosystem Study, http://www.hubbardbrook.org/data/dataset.php?id=8.

Likens, G. E. 2012c. Chemistry of Streamwater at HBEF WS-5. Hubbard Brook Ecosystem Study, http://www.hubbardbrook.org/data/dataset.php?id=7.

Likens, G. E., and F. H. Bormann. 1995. Biogeochemistry of a Forested Ecosystem, 2nd edition. Springer-Verlag, New York. 
Likens, G. E., C. T. Driscoll, and D. C. Buso. 1996. Long-term effects of acid rain: response and recovery of a forest ecosystem. Science 272:244-246. doi: 10.1126/science.272.5259.244.

Likens, G. E., C. T. Driscoll, D. C. Buso, T. G. Siccama, C. E. Johnson, G. M. Lovett, T. J. Fahey, W. A. Reiners, D. F. Ryan, C. W. Martin, and S. W. Bailey. 1998. The biogeochemistry of calcium at Hubbard Brook. Biogeochemistry 41:89-173. doi: 10.1023/A:1005984620681.

Likens, G. E., C. T. Driscoll, D. C. Buso, T. G. Siccama, C. E. Johnson, G. M. Lovett, D. F. Ryan, T. J. Fahey, and W. A. Reiners. 1994. The biogeochemistry of potassium at Hubbard Brook. Biogeochemistry 25:61-125.

Lovett, G. M., J. J. Bowser, and E. S. Edgerton. 1997. Atmospheric deposition to watersheds in complex terrain. Hydrological Processes 11:645-654. doi: 10.1002/(SICI)10991085(199706)11:7<645::AID-HYP526>3.3.CO;2-U.

Lyons, J. B., W. A. Bothner, R. H. Moench, and J. B. Thompson. 1997. Bedrock Geologic Map of New Hampshire. US Geological Survey, Reston, VA.

Malmsheimer, R. W., P. Heffernan, S. Brink, D. Crandall, F. Deneke, C. Galik, E. A. Gee, J. A. Helms, N. McClure, M. Mortimer, S. Ruddell, M. Smith, and J. Stewart. 2008. Forest management solutions for mitigating climate change in the United States. Journal of Forestry 106:115-171.

Marchand, D. E. 1971. Rates and modes of dunudation, White Mountains, eastern California. American Journal of Science 270:109-115. doi: 10.2475/ajs.270.2.109.

Marschner, H. 1995. Mineral Nutrition of Higher Plants, 2nd edition. Academic Press, San Diego.

Meerts, P. 2002. Mineral nutrient concentrations in sapwood and heartwood : a literature review. Annals of Forest Science 59:713-722. doi: 10.1051/forest:2002059.

Melson, S. L., M. E. Harmon, J. S. Fried, and J. B. Domingo. 2011. Estimates of live-tree carbon stores in the Pacific Northwest are sensitive to model selection. Carbon Balance and Management 6:2. doi: 10.1186/1750-0680-6-2.

Newman, E. I. 1995. Phosphorus inputs to terrestrial ecosystems. Journal of Ecology 83:713-726.

Nezat, C. A., J. D. Blum, A. Klaue, C. E. Johnson, and T. G. Siccama. 2004. Influence of landscape position and vegetation on long-term weathering rates at the Hubbard Brook Experimental Forest, New Hampshire, USA. Geochimica et Cosmochimica Acta 68:3065-3078. doi: 10.1016/j.gca.2004.01.021.

Nezat, C. A., J. D. Blum, R. D. Yanai, and S. P. Hamburg. 2007. A sequential extraction to determine the distribution of apatite in granitoid soil mineral pools with application to weathering at the Hubbard Brook Experimental Forest, NH, USA. Applied Geochemistry 22:2406-2421. doi: 10.1016/j.apgeochem.2007.06.012.

Nezat, C. A., J. D. Blum, R. D. Yanai, and B. B. Park. 2008. Mineral sources of calcium and phosphorus in soils of the northeastern United States. Soil Science Society of America Journal 72:1786-1794. doi: 10.2136/sssaj2007.0344.

Olsson, M. T., and P.-A. Melkerund. 2000. Weathering in three podzolized pedons on glacial deposits in northern Sweden and central Finland. Geoderma 94:149-161. doi: 10.1016/S0016-7061(99)000816.

Orwin, K. H., M. U. F. Kirschbaum, M. G. St. John, and I. A. Dickie. 2011. Organic nutrient uptake by mycorrhizal fungi enhances ecosystem carbon storage: a model-based assessment. Ecology Letters 14:493-502. doi: 10.1111/j.1461-0248.2011.01611.x. 
Park, B. B., R. D. Yanai, M. A. Vadeboncoeur, and S. P. Hamburg. 2007. Estimating root biomass in rocky soils using pits, cores, and allometric equations. Soil Science Society of America Journal 71:206-213. doi: 10.2136/sssaj2005.0329.

Peñuelas, J., J. Sardans, A. Rivas-Ubach, and I. A. Janssens. 2012. The human-induced imbalance between C, N and P in Earth's life system. Global Change Biology 18:3-6. doi: 10.1111/j.13652486.2011.02568.x.

Pitman, R. M. 2006. Wood ash use in forestry - a review of the environmental impacts. Forestry 79:563588. doi: 10.1093/forestry/cpl041.

Rastetter, E. B., and G. R. Shaver. 1992. A model of multiple-element limitation for acclimating vegetation. Ecology 73:1157-1174. doi: 10.2307/1940666.

Rastetter, E. B., R. D. Yanai, R. Q. Thomas, M. A. Vadeboncoeur, T. J. Fahey, M. C. Fisk, B. L. Kwiatkowski, and S. P. Hamburg. 2013. Recovery from disturbance requires resynchronization of ecosystem nutrient cycles. Ecological Applications 23:621-642. doi: 10.1890/12-0751.1.

Reiners, W. A., K. L. Driese, T. J. Fahey, and K. G. Gerow. 2012. Effects of three years of regrowth inhibition on the resilience of a clear-cut northern hardwood forest. Ecosystems 15:1351-1362. doi: 10.1007/s10021-012-9589-0.

Richter, D. D., D. H. Jenkins, J. T. Karakash, J. Knight, L. R. McCreery, and K. P. Nemestothy. 2009. Wood energy in America. Science 323:1432-1433. doi: 10.1126/science.1166214.

Robinson, G. R. 1997. Portraying chemical properties of bedrock for water quality and ecosystem analysis: an approach for the New England region. United States Geological Survey Open-File Report 97-154, Reston, VA.

Romanowicz, R. B., C. T. Driscoll, C. E. Johnson, T. J. Fahey, G. E. Likens, and T. G. Siccama. 1996. Changes in the biogeochemistry of potassium following a whole-tree harvest. Soil Science Society of America Journal 60:1664-1674. Soil Sci Soc America. doi: 10.2136/sssaj1996.03615995006000060009x.

Rosling, A., B. D. Lindahl, and R. D. Finlay. 2004. Carbon allocation to ectomycorrhizal roots and mycelium colonising different mineral substrates. New Phytologist 162:795-802. doi: 10.1111/j.1469-8137.2004.01080.x.

Schaller, M., J. D. Blum, S. P. Hamburg, and M. A. Vadeboncoeur. 2010. Spatial variability of long-term chemical weathering rates in the White Mountains, New Hampshire, USA. Geoderma 154:294-301. Elsevier B.V. doi: 10.1016/j.geoderma.2009.10.017.

Siccama, T. G. 2007. Hubbard Brook Landscape Biomass Program. Hubbard Brook Ecosystem Study, http://www.hubbardbrook.org/w6_tour/biomass-stop/biomassw6.htm.

Smil, V. 2000. Phosphrous in the environment: natural flows and human interferences. Annual Review of Energy and the Environment 25:53-88. doi: 10.1146/annurev.energy.25.1.53.

Smith, D. B., W. F. Cannon, and L. G. Woodruff. 2011. A national-scale geochemical and mineralogical survey of soils of the conterminous United States. Applied Geochemistry 26:S250-S255. Elsevier Ltd. doi: 10.1016/j.apgeochem.2011.03.116.

Smits, M. M., S. Bonneville, L. G. Benning, S. A. Banwart, and J. R. Leake. 2012. Plant-driven weathering of apatite - the role of an ectomycorrhizal fungus. Geobiology 10:445-56. doi: 10.1111/j.1472-4669.2012.00331.x.

Stelzer, R. S., G. E. Likens, D. C. Buso, and J. H. J. McCutchan. 2002. Seasonal variation of phosphorus in precipitation at Hubbard Brook Experimental Forest. Verhandlungen des Internationalen Verein Limnologie 28:1211-1215. 
Stupak, I., A. Asikainen, D. Röser, and K. Pasanen. 2008. Review of recommendations for forest energy harvesting and wood ash recycling. Pages 155-196 in D. Röser, A. Asikainen, K. RaulundRasmussen, and I. Stupak, editors. Sustainable Use of Forest Biomass for Energy - A Synthesis with Focus on the Baltic and Nordic Region. Springer. doi: 10.1007/978-1-4020-5054-1_7.

Sverdrup, H., and M. G. E. Svensson. 2002. Defining Sustainability. Pages 21-32 in H. Sverdrup and I. Stjernquist, editors. Developing principles and models for sustainable forestry in Sweden. Kluwer Academic Publishers, Boston.

Taylor, A., and J. D. Blum. 1995. Relation between soil age and silicate weathering rates determined from the chemical evolution of a glacial chronosequence. Geology 23:979-982. doi: 10.1130/00917613(1995)023<0979:RBSAAS >2.3.CO;2.

Thiffault, E., K. D. Hannam, D. Paré, B. D. Titus, P. W. Hazlett, D. G. Maynard, and S. Brais. 2011. Effects of forest biomass harvesting on soil productivity in boreal and temperate forests - a review. Environmental Reviews 19:278-309. doi: 10.1139/A11-009.

Tremblay, S., R. Ouimet, D. Houle, and L. Duchesne. 2012. Base cation distribution and requirement of three common forest ecosystems in eastern Canada based on site-specific and general allometric equations. Canadian Journal of Forest Research 42:1796-1809. doi: 10.1139/x2012-125.

Treseder, K. K. 2004. A meta-analysis of mycorrhizal responses to nitrogen, phosphorus, and atmospheric $\mathrm{CO}_{2}$ in field studies. New Phytologist 164:347-355. doi: 10.1111/j.1469-8137.2004.01159.x.

Vadeboncoeur, M. A. 2010. Meta-analysis of fertilization experiments indicates multiple limiting nutrients in northeastern deciduous forests. Canadian Journal of Forest Research 40:1766-1780. doi: 10.1139/X10-127.

Vadeboncoeur, M. A. 2013. Mechanisms of nutrient limitation and nutrient acquisition in managed and unmanaged forest ecosystems. Ph.D. Dissertation, University of New Hampshire. http://scholars.unh.edu/dissertation/1/

Vadeboncoeur, M. A., S. P. Hamburg, J. D. Blum, M. J. Pennino, R. D. Yanai, and C. E. Johnson. 2012. The quantitative soil pit method for measuring belowground carbon and nitrogen stocks. Soil Science Society of America Journal 76:2241-2255. doi: 10.2136/sssaj2012.0111.

Van Doorn, N. S., J. J. Battles, T. J. Fahey, T. G. Siccama, and P. A. Schwarz. 2011. Links between biomass and tree demography in a northern hardwood forest: a decade of stability and change in Hubbard Brook Valley, New Hampshire. Canadian Journal of Forest Research 41:1369-1379. doi: 10.1139/x11-063.

Van Scholl, L., T. W. Kuyper, M. M. Smits, R. Landeweert, E. Hoffland, and N. van Breemen. 2008. Rock-eating mycorrhizas: their role in plant nutrition and biogeochemical cycles. Plant and Soil 303:35-47. doi: 10.1007/s11104-007-9513-0.

Vicca, S., S. Luyssaert, J. Peñuelas, M. Campioli, F. S. Chapin, P. Ciais, A. Heinemeyer, P. Högberg, W. L. Kutsch, B. E. Law, Y. Malhi, D. Papale, S. L. Piao, M. Reichstein, E.-D. Schulze, and I. A. Janssens. 2012. Fertile forests produce biomass more efficiently. Ecology Letters 15:520-526. doi: 10.1111/j.1461-0248.2012.01775.x.

Walker, T., P. Cardellichio, A. Colnes, J. Gunn, B. Kittler, R. T. Perschel, C. Recchia, and D. Saah. 2010. Biomass sustainability and carbon policy study. Page 182. Manomet Center for Conservation Sciences, Manomet, MA.

Wallander, H., and T. Wickman. 1999. Biotite and microcline as potassium sources in ectomycorrhizal and non-mycorrhizal Pinus sylvestris seedlings. Mycorrhiza 9:25-32. doi: 10.1007/s005720050259. 
Weathers, K. C., S. M. Simkin, G. M. Lovett, and S. E. Lindberg. 2006. Empirical modeling of atmospheric deposition in mountainous landscapes. Ecological Applications 16:1590-1607.

White, E. H. 1974. Whole-tree harvesting depletes soil nutrients. Canadian Journal of Forest Research 4:530-535.

Wood, T., F. H. Bormann, and G. K. Voigt. 1984. Phosphorus cycling in a northern hardwood forest: biological and chemical control. Science 223:391-393.

Worrell, R., and A. Hampson. 1997. The influence of some forest operations on the sustainable management of forest soils - a review. Forestry 70:61-85.

Yanai, R. D. 1992. Phosphorus budget of a 70-year-old northern hardwood forest. Biogeochemistry 17:122. doi: 10.1007/BF00002757.

Yanai, R. D., J. D. Blum, S. P. Hamburg, M. A. Arthur, C. A. Nezat, and T. G. Siccama. 2005. New insights into calcium depletion in northeastern forests. Journal of Forestry 103:14-20.

Yanai, R. D., C. R. Levine, M. B. Green, and J. L. Campbell. 2012. Quantifying uncertainty in forest nutrient budgets. Journal of Forestry 110:448-456. doi: 10.5849/jof.11-087.

Yanai, R. D., B. B. Park, and S. P. Hamburg. 2006. The vertical and horizontal distribution of roots in northern hardwood stands of varying age. Canadian Journal of Forest Research 36:450-459. doi: 10.1139/x05-254.

Yanai, R. D., M. A. Vadeboncoeur, S. P. Hamburg, M. A. Arthur, C. B. Fuss, P. M. Groffman, T. G. Siccama, and C. T. Driscoll. 2013. From missing source to missing sink: Long-term changes in the nitrogen budget of a northern hardwood forest. Environmental Science \& Technology 47:11440 11448. doi: 10.1021/es4025723. 
$\underline{\text { Table } 1}$

861 Long-term soil weathering rates and watershed-scale denudation rates $\left(\mathrm{kg} \mathrm{ha}^{-1} \mathrm{y}^{-1}\right)$ for granitic

862 soil in the study region and elsewhere. Long-term weathering rates are derived from the

863 depletion of each element relative to an immobile reference element, assuming that the $\mathrm{C}$ horizon

864 represents unweathered parent material. Denudation rates are estimated from watershed budgets

865 in which major fluxes are measured and weathering is assumed to account for the missing term

866 required to achieve mass balance.

\begin{tabular}{|c|c|c|c|c|c|}
\hline a) Long-term soil profile weathering rates & $\begin{array}{c}\text { Soil age } \\
\text { (ka) }\end{array}$ & Ca & K & Mg & $\mathbf{P}$ \\
\hline in study region: & & & & & \\
\hline Schaller et al. (2010) regional mean & 14 & 0.59 & 2.11 & 0.33 & 0.043 \\
\hline range of 13 site rates used in this study & & $0.11-1.14$ & $0.42-4.23$ & $0.06-0.91$ & $0.017-$ \\
\hline Nezat et al. (2004), HBEF W1 & 14 & 1.46 & 4.18 & 0.51 & 0.114 \\
\hline in studies also reporting denudation rates (see b & elow): & & & & \\
\hline April et al. (1986), New York & 14 & $2.0-3.6$ & $5.0-5.9$ & $1.0-1.5$ & \\
\hline Kirkwood and Nesbitt (1991), Ontario & 12 & 2.6 & 2.8 & 1.0 & \\
\hline Bain et al. (2001), Scotland & & $0.04-0.10$ & $0.11-0.45$ & $.006-0.035$ & \\
\hline other rates for reference: & & & & & \\
\hline Taylor and Blum (1995), Wyoming & $11-21$ & $1.1-1.7$ & $1.0-1.9$ & 0.015 & \\
\hline Egli et al. (2008), Switzerland and Italy & $12-16$ & $0.0-4.3$ & $0.04-3.7$ & $0.11-4.7$ & \\
\hline Olsson and Melkerund (2000), Sweden \& Finland & 9 & $1.4-1.6$ & $0.6-1.6$ & $1.6-2.4$ & $\sim 0.01$ \\
\hline Newman (1995), New Zealand & $6-12$ & & & & $0.1-0.3$ \\
\hline
\end{tabular}


Table 1, continued

b) Denudation rates from watershed budgets

in study region:

Bailey et al. (1996), Cone Pond

Hyman et al. (1998), Cone Pond

Likens and Bormann (1995), HBEF *

Likens et al. (1998), HBEF

Wood et al. (1984), HBEF*

in studies also reporting long-term weathering rates

April et al. (1986), New York

Kirkwood and Nesbitt (1991), Ontario

Bain et al. (2001), Scotland

other rates for reference:

Marchand (1971), California

Lelong et al. (1990), France

Clayton and Megahan (1986), Idaho

$\begin{array}{llll}\mathrm{Ca} & \mathrm{K} & \mathrm{Mg} & \mathrm{P}\end{array}$

$1.2-3.3$

$\begin{array}{lll}2.18 & 1.08 & 1.09\end{array}$

$\begin{array}{lll}21.1 & 7.1 & 3.5\end{array}$

$2.00-3.12$

$1.5-1.8$

$\begin{array}{rrr}3.3-23.0 & 0-1.3 & 0.3-3.6 \\ 10.8 & 0.2 & 2.6 \\ 1.6 & & 2.6\end{array}$

$\begin{array}{rrrr}17 & 1.1 & 1.8 & 0.03 \\ 2.7-11.2 & 2.8-6.5 & 2.4-5.5 & \\ 13.6 & 1.63 & 1.43 & \end{array}$

868 * Probably greatly overestimated due to budget error (Likens et al. 1994, Likens and Bormann 1995). 
Table 2

870 Description of the stands used in the study. "Cuts" indicates the number of times a site had been

871 harvested as of 2004. Sites are ordered geographically from southwest to northeast (Figure 1).

872 The "C" and " $\mathrm{H}$ " sites within the Bartlett Experimental Forest are ordered by stand age

873 (youngest to oldest).

874

\begin{tabular}{|c|c|c|c|c|c|c|c|}
\hline & Bedrock & $\begin{array}{r}\text { Elev. } \\
\text { (m) }\end{array}$ & $\begin{array}{r}\mathrm{FF} \\
(\mathrm{cm})\end{array}$ & $\begin{array}{r}\text { Depth } \\
\text { to C } \\
(\mathrm{cm})\end{array}$ & $\begin{array}{r}\text { Rock } \\
\text { vol. } \\
(\%)\end{array}$ & $\begin{array}{l}\text { Age } \\
\text { (yrs) }\end{array}$ & Cuts \\
\hline BW & Concord granite & 570 & 12 & 30 & 26 & $>100$ & $\overline{\sim 1}$ \\
\hline B1 & Concord granite & 490 & 5 & 36 & 19 & $\sim 70$ & 1 \\
\hline HBEF & Rangeley schist & 600 & 7 & 50 & 18 & $70-100$ & $\sim 1$ \\
\hline M6 & Conway granite & 540 & 5 & 66 & 34 & 23 & 2 \\
\hline C1 & Mt Osceola granite & 570 & 2 & 74 & 36 & 14 & 2 \\
\hline C2 & Conway granite & 340 & 4 & 73 & 26 & 16 & 2 \\
\hline H6 & Conway granite & 330 & $6^{*}$ & 61 & 17 & 19 & 2 \\
\hline $\mathrm{C} 4$ & Conway granite & 410 & 5 & 78 & 15 & 26 & 2 \\
\hline C6 & Conway granite & 460 & 6 & 38 & 15 & 28 & 2 \\
\hline H4 & Conway granite & 350 & 4 & 73 & 25 & 64 & 2 \\
\hline H1 & Conway granite & 320 & 5 & 68 & 14 & 68 & 2 \\
\hline C8 & Mt Osceola granite & 330 & 3 & 74 & 31 & $\sim 120$ & 1 \\
\hline C9 & Conway granite & 440 & 8 & 85 & 33 & $\sim 120$ & 1 \\
\hline T30 & Rangeley schist & 550 & 6 & 48 & 23 & 55 & 2 \\
\hline M5 & Rangeley schist & 630 & 7 & 48 & 36 & 26 & 2 \\
\hline
\end{tabular}

875

$876 *$ Randomly located soil pits at H6 appear to have overestimated the Oa horizon relative to more extensive pin-block samples taken across the 877 stand in the same year (Vadeboncoeur et al. 2012). Pin-block data are reported here. 


\section{$878 \underline{\text { Table } 3}$}

879 Scenarios used in the analysis of nutrient depletion by biomass removal.

\section{$\underline{\text { Input/output budget data scenarios }}$}

I HBEF observed precipitation inputs.

Stand-specific weathering rates from profile depletion relative to $\mathrm{Ti}$.

Non-harvest-associated leaching $=0$.

II HBEF observed precipitation inputs.

Weathering rates inferred from HBEF ecosystem budgets

Non-harvest-associated leaching observed at $\mathrm{HBEF}$

\section{Biomass harvest scenarios}

a Stem-only removal on 100 y interval

b Whole-tree removal on $100 \mathrm{y}$ interval

c Whole-tree removal on 35 y interval

\section{$\underline{\text { Nutrient availability scenarios }}$}

1 Weathering rate assumed in I or II cannot change; only exchangeable and organically bound stocks are available over multiple rotations

2 Weathering rate may change in response to demand. Apatite in the B horizon is also available, in addition to exchangeable and organic stocks

3 Weathering rate and rooting depth may change in response to demand. Apatite in the B and top $25 \mathrm{~cm}$ of the $\mathrm{C}$ horizon are available, in addition to exchangeable and organic stocks 


\section{Table 4}

881 Net nutrient stock changes per rotation under three scenarios of harvest intensity and two nutrient budget scenarios. These were

882 combined to calculate net stock changes per rotation, which were applied to each site under various scenarios of nutrient availability.

\begin{tabular}{|c|c|c|c|c|c|c|c|c|c|c|c|c|c|c|}
\hline \multirow[b]{2}{*}{ Scenario } & \multicolumn{4}{|c|}{$\begin{array}{l}\text { stock removed per harvest } \\
\qquad\left(\mathrm{kg} \mathrm{ha}^{-1}\right)\end{array}$} & \multicolumn{4}{|c|}{$\begin{array}{l}\text { other fluxes in budget } \\
\qquad\left(\mathrm{kg} \mathrm{ha}^{-1} \mathrm{y}^{-1}\right)\end{array}$} & calct & $\begin{array}{l}\text { lated } \mathrm{n} \\
\text { in } \mathrm{e}\end{array}$ & stock c & $\begin{array}{l}\text { ange } \mathrm{p} \\
\text { io }(\mathrm{kg}\end{array}$ & $\begin{array}{l}r 100 s \\
\left.a^{-1}\right)\end{array}$ & ars \\
\hline & $\mathrm{a}$ & $\mathrm{b}$ & $\mathrm{c}$ & all & all & I & $\begin{array}{c}\text { II } \\
\text { budget- }\end{array}$ & II & $\mathrm{Ia}^{*}$ & $\mathrm{Ib}^{*}$ & $\mathrm{Ic}^{*}$ & IIa & IIb & III \\
\hline & & & & harvest & & mean & inferred & observed & & & & & & \\
\hline & $100 y$ & $100 \mathrm{y}$ & $35 y$ & related & precip & baseline & weather- & stream & & & & & & \\
\hline & stem- & whole- & whole- & leach- & input at & weather- & ing input & output at & & & & & & \\
\hline element & only & tree & tree & ing & HBEF & ing* & at $\mathrm{HBEF}$ & HBEF & & & & & & \\
\hline $\mathrm{Ca}$ & 296 & 456 & 359 & 74 & 1.12 & 0.59 & 2.28 & 7.24 & -198 & -359 & -1066 & -754 & -914 & -1621 \\
\hline K & 99 & 189 & 150 & 47 & 0.64 & 2.20 & 1.08 & 1.76 & +137 & +48 & -279 & -150 & -240 & -567 \\
\hline $\mathrm{Mg}$ & 26 & 40 & 30 & 16 & 1.09 & 0.25 & 1.09 & 2.09 & +15 & +2 & -74 & -109 & -123 & -198 \\
\hline $\mathrm{P}$ & 17 & 28 & 19 & 0 & 0.18 & 0.043 & 0.18 & 0.011 & -6 & -18 & -44 & +6 & -5 & -31 \\
\hline $\mathrm{N}$ & 222 & 395 & 349 & 50 & 8.0 & 0 & 0 & 2.6 & +528 & +355 & -340 & +268 & +95 & -600 \\
\hline
\end{tabular}

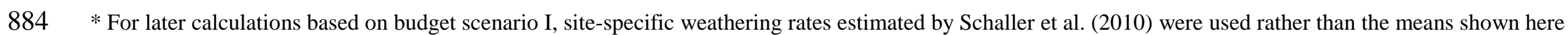
885 as an example. 
887 Soil nutrient stocks measured at each site.

\begin{tabular}{|c|c|c|c|c|c|c|c|c|c|}
\hline & \multicolumn{5}{|c|}{ exchangeable and organic thru B } & \multicolumn{2}{|c|}{ apatite in B horizon } & \multicolumn{2}{|c|}{ of $\mathrm{C}$ horizon } \\
\hline & $\mathrm{Ca}$ & K & $\mathrm{Mg}$ & $\mathrm{P}$ & $\mathrm{N}$ & $\mathrm{Ca}$ & $\bar{P}$ & $\mathrm{Ca}$ & $\mathrm{P}$ \\
\hline BW & 1125 & 176 & 153 & 178 & 5298 & 405 & 222 & 4985 & 1927 \\
\hline B1 & 546 & 152 & 80 & 125 & 5322 & 1114 & 674 & 5937 & 2581 \\
\hline HBEF & 308 & 162 & 61 & 194 & 8608 & 647 & 534 & 1408 & 913 \\
\hline M6 & 594 & 199 & 45 & 109 & 7752 & 69 & 91 & 32 & 116 \\
\hline C1 & 274 & 260 & 28 & 38 & 3688 & 212 & 109 & 188 & 130 \\
\hline C2 & 523 & 214 & 43 & 56 & 4265 & 148 & 59 & 247 & 114 \\
\hline H6* & 820 & 219 & 52 & 106 & 5365 & 625 & 493 & 697 & 387 \\
\hline C4 & 341 & 198 & 37 & 58 & 5051 & 73 & 61 & 194 & 150 \\
\hline C6 & 373 & 144 & 35 & 73 & 5277 & 136 & 64 & 405 & 313 \\
\hline H4 & 533 & 220 & 43 & 72 & 6895 & 411 & 365 & 110 & 68 \\
\hline H1 & 499 & 224 & 40 & 100 & 6338 & 179 & 151 & 262 & 152 \\
\hline C8 & 567 & 157 & 34 & 62 & 4143 & 586 & 390 & 1054 & 454 \\
\hline C9 & 471 & 174 & 32 & 104 & 6590 & 1266 & 850 & 1238 & 585 \\
\hline T30 & 755 & 278 & 74 & 116 & 5047 & 562 & 591 & 1269 & 757 \\
\hline M5 & 684 & 196 & 98 & 113 & 5673 & 657 & 483 & 0 & 0 \\
\hline
\end{tabular}

888

$889 *$ Oa horizon nutrient content estimates for site $\mathrm{H} 6$ are scaled to the mass difference observed between the soil pits

890 and the more extensive pin block samples taken in the same year. $\mathrm{N}$ content of the Oa was measured directly on the 891 pin block samples.

892 


\section{$893 \underline{\text { Table } 6}$}

894 Number of 100-year whole-tree harvest rotations required to exhaust B-horizon and B+C-

895 horizon apatite stocks, if $\mathrm{Ca}$ or $\mathrm{P}$ ultimately limits production. Weathering of non-apatite $\mathrm{Ca}$ was 896 assumed constant at long-term rates (Table 1).

\begin{tabular}{|c|c|c|c|c|}
\hline & \multicolumn{2}{|c|}{$\begin{array}{c}\text { exch }+ \text { org }+ \text { apatite } \\
\text { thru B } \\
(\text { Scenario I2b) }\end{array}$} & \multicolumn{2}{|c|}{$\begin{array}{c}\text { exch }+ \text { org + apatite } \\
\text { thru C25cm } \\
(\text { Scenario I3b) }\end{array}$} \\
\hline & $\mathrm{Ca}$ & $\mathbf{P}$ & $\mathbf{C a}$ & $\mathbf{P}$ \\
\hline BW & 4.2 & 21 & 18 & 108 \\
\hline B1 & 5.1 & 37 & 23 & 154 \\
\hline HBEF & 3.2 & 33 & 8.0 & 75 \\
\hline M6 & 1.7 & 10 & 1.8 & 15 \\
\hline C1 & 1.3 & 7 & 1.8 & 13 \\
\hline $\mathrm{C} 2$ & 1.8 & 6 & 2.4 & 11 \\
\hline H6 & 3.7 & 27 & 5.4 & 45 \\
\hline $\mathrm{C} 4$ & 1.2 & 6 & 1.7 & 13 \\
\hline C6 & 1.4 & 7 & 2.6 & 21 \\
\hline H4 & 2.5 & 20 & 2.8 & 23 \\
\hline H1 & 1.7 & 13 & 2.3 & 20 \\
\hline $\mathrm{C8}$ & 3.4 & 21 & 6.4 & 42 \\
\hline C9 & 5.0 & 45 & 8.6 & 72 \\
\hline T30 & 3.2 & 33 & 6.3 & 67 \\
\hline M5 & 3.6 & 29 & 3.6 & 29 \\
\hline
\end{tabular}

897

898 


\section{$899 \quad$ Table 7}

900 Total biomass (dry metric tons) harvestable before nutrient exhaustion (Figure 2) from each site

901 under budget scenario I, availability scenario 1 , and each of the three harvest intensity scenarios.

\begin{tabular}{lrrr} 
site & $\begin{array}{r}100 \mathrm{y} \\
\text { bole } \\
\text { only }\end{array}$ & $\begin{array}{r}100 \mathrm{y} \\
\text { whole } \\
\text { tree }\end{array}$ & $\begin{array}{r}35 \mathrm{y} \\
\text { whole } \\
\text { tree }\end{array}$ \\
\hline BW & 578 & 256 & 172 \\
B1 & 482 & 218 & 148 \\
HBEF & 355 & 212 & 140 \\
M6 & 345 & 291 & 243 \\
C1 & 178 & 143 & 115 \\
C2 & 320 & 264 & 214 \\
H6 & 475 & 401 & 262 \\
C4 & 241 & 186 & 145 \\
C6 & 255 & 200 & 158 \\
H4 & 341 & 276 & 222 \\
H1 & 274 & 236 & 202 \\
C8 & 437 & 323 & 164 \\
C9 & 354 & 265 & 174 \\
T30 & 395 & 347 & 302 \\
M5 & 445 & 357 & 286 \\
\hline mean & $\mathbf{3 8 8}$ & $\mathbf{2 8 4}$ & $\mathbf{2 0 6}$ \\
\hline
\end{tabular}

902 


\section{Figure 1}

904 Location of the 15 sites used in this study. The wedge-shaped areas to the northwest of each site

905 outline the approximate till source area for each site (Hornbeck et al. 1997). Geologic data are

906 simplified from Lyons et al. (1997).

907

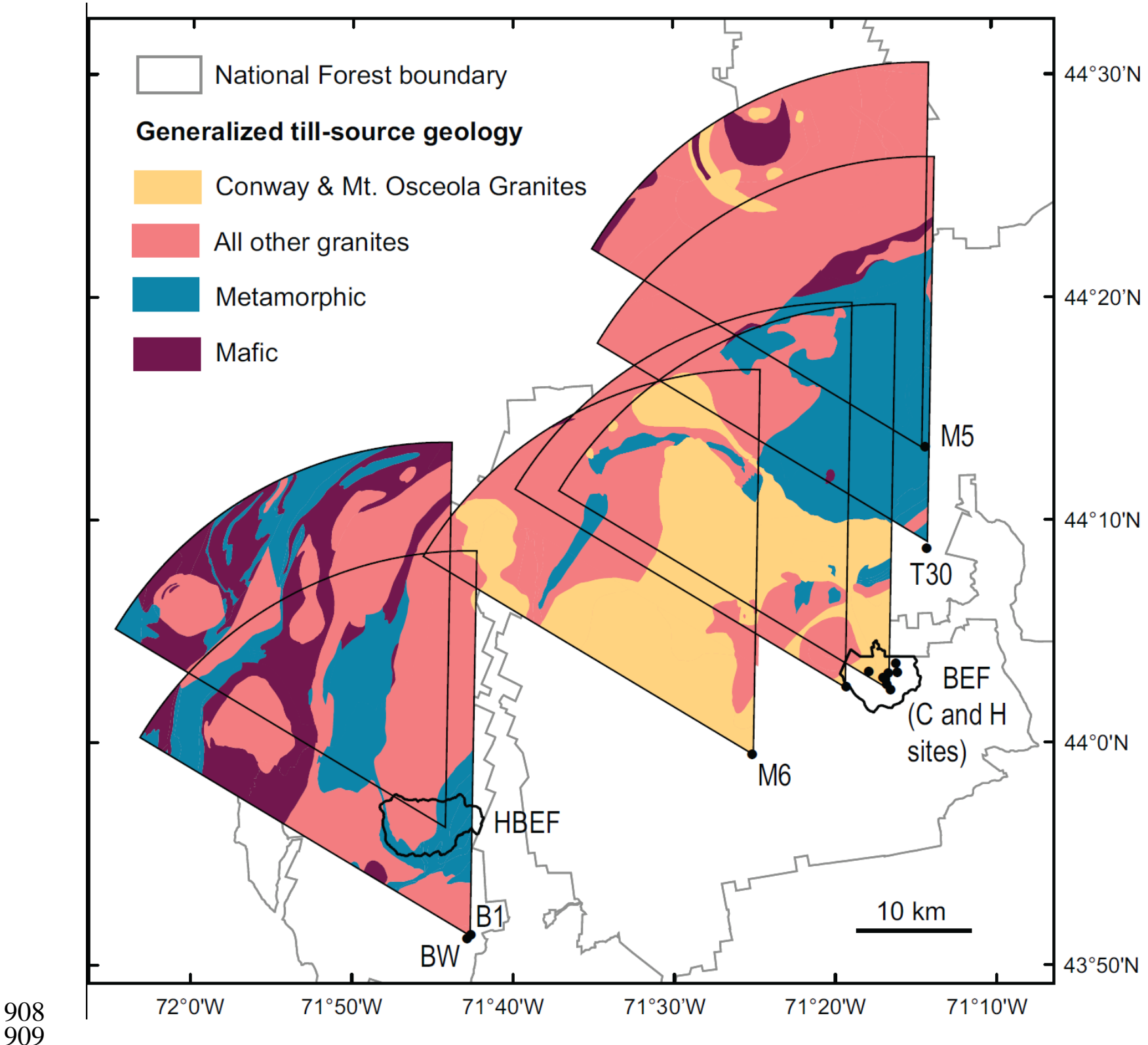




\section{$910 \quad$ Figure 2}

911 Times to nutrient depletion in three harvest scenarios across 15 sites, assuming that weathering

912 proceeds at the long-term baseline value (Budget scenario I), and that only exchangeable and

913 organically bound nutrients are available on the time scale of multiple rotations (Availability

914 scenario 1). All three harvest scenarios are shown. Calcium is the first nutrient exhausted in all

915 scenarios except those indicated for potassium or magnesium.

916

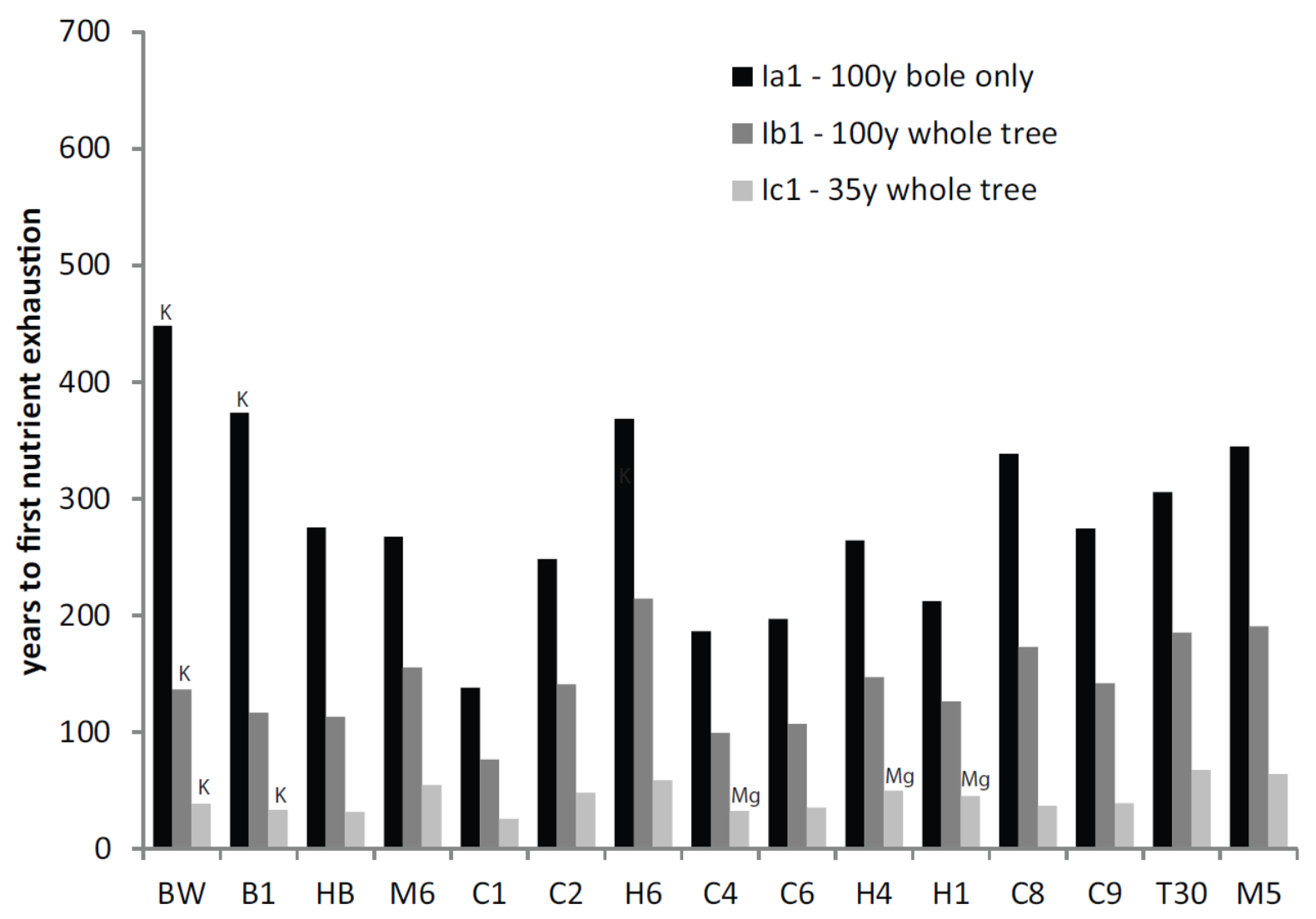

